\title{
FIQH AL-HADÎTS: Perspektif Historis dan Metodologis
}

\author{
Saifuddin \\ Jurusan Tafsir Hadis Fakultas Ushuluddin IAIN Antasari \\ Jl. A. Yani Km. 4,5 Banjarmasin \\ Diterima tanggal 24 April 2012 / Disetujui tanggal 27 Juni 2012
}

\begin{abstract}
Study of fiqh hadith Sharh Hadith is one of interested topic to discuss. Study of fiqh al-Hadith is a multidisciplinary field of study that involves almost all branches of hadith disciplines, involving sanad sciences, Rijal al-Hadith sciences, as well as matn sciences. The science is in its infancy still simple, then grow gradually and extends to become an independent branch of science known as Sharh Hadith al-hadith or fiqh.
\end{abstract}

Kata kunci: fiqh al-hadîts, syarh al-hadits, pendekatan, metodologi

\section{Pendahuluan}

Studi fiqh al-hadits dan syarah hadis termasuk salah satu topik kajian yang menarik untuk diangkat. Sejauh ini, muncul kegelisahan bahwa bidangbidang kajian yang dikembangkan dalam studi hadis, termasuk di Fakultas Ushuluddin, hanya berkisar pada kualitas sanad dan matan saja, sementara kajian dalam rangka memahami kandungan matannya hampir tidak ditemukan. Bahkan, kalaupun ada pemahaman kandungan matan hadisnya hanya mengemukakan syarah-syarah dari para ulama saja, sama sekali tidak menyentuh aspek metodologisnya. ${ }^{1}$

Studi hadis sendiri pada dasarnya dapat dipetakan menjadi tiga level utama. Pertama, studi terhadap teks hadis dalam hubungannya dengan Nabi Muhammad saw. Hal ini misalnya terjadi pada kritik sanad yang menguji apakah suatu hadis benar-benar dari Nabi saw., dengan cara mengkaji kredibilitas para periwayatnya. Analisis sebenarnya bisa diarahkan pada

\footnotetext{
${ }^{1}$ Kegelisahan semacam ini misalnya dapat dilihat dalam Proposal Seminar Regional

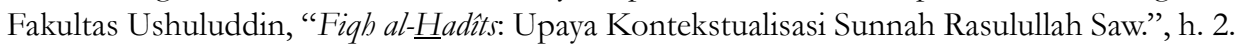


aspek-aspek psikologis Nabi saw. ketika menyampaikan hadis (qauli), melakukan suatu perbuatan $(f i r)$, ataupun sikap (taqrîi $)$. Kedua, studi terhadap teks hadis itu sendiri. Hal ini terkait dengan, misalnya, kritik matan, pengkajian terhadap kitab-kitab hadis, dan aktivitas pensyarahan yang dilakukan seorang pensyarah atau pengkaji. Ketiga, studi terhadap teks hadis dalam hubungannya dengan masyarakat pembaca/pensyarahnya. Hal ini misalnya, terjadi pada pengkajian atas produk syarah (kitab-kitab syarah) dan pengajaran hadis di lembaga-lembaga pendidikan Islam (surau, madrasah, pesantren, perguruan tinggi, dan lain-lain), penyampaian hadis di khutbah-khutbah, pengajian-pengajian, dan lain-lain. ${ }^{2}$

Dari ketiga level studi hadis yang telah dijelaskan, tampaknya kajian kritik sanad (naqd al-sanad) dan kritik matan (naqd al-matn) menempati posisi yang dominan. Karena kuatnya tarikan gravitasi pada studi kritik sanad dan matan hadis ini tidak mengherankan jika kemudian muncul kritikan bahwa studi hadis menjadi bidang yang sangat kaku, rigid, dan sensitif. Sejak awal, bidang studi hadis menjadi bidang yang monolitik. Pendekatan yang dianggap sah adalah kritik sanad (naqd al-sanad) dan kritik matan (naqd al-matn), itu pun dibatasi dengan aturan-aturan yang sangat ketat. Hal ini mungkin disebabkan oleh adanya hadis Nabi saw. yang menyatakan, "Barangsiapa yang berdusta atas namaku, maka dia menyediakan tempatnya pada api neraka." Kritik sanad menekankan penilaian positif dan negatif (al-jarh wa al-ta'dîl) terhadap keadilan, kejujuran, dan kekuatan hafalan periwayat. Sedangkan kritik matan lebih terfokus pada masalah-masalah tanda baca, seperti titik, fahthah, kasrah, dan dammah. Kritik ini hampir tidak menyentuh isi (contens), karena yang terakhir masuk dalam genre lain, yakni syarah hadis. Dalam pengertian ini, menurut Nur Ichwan, seharusnya era kritik sanad dan kritik matan dianggap sudah selesai, namun kenyataannya tidak demikian. Studi hadis lebih menekankan pada pengulangan-pengulangan daripada pengembangan. ${ }^{3}$ Kritikan yang hampir

${ }^{2}$ Moch. Nur Ichwan, “Beberapa Gagasan tentang Pengembangan Studi al-Qur'an dan Hadis: Refleksi atas Perkembangan Jurusan Tafsir Hadis di Indonesia”, dalam Sahiron Syamsuddin et al., Hermeneutika al-Qur'an Mą̧bab Yogya, (Yogyakarta: Penerbit Islamika, 2003), h. 240-241.

${ }^{3}$ Ichwan, "Beberapa Gagasan”, h. 240. 
sama juga sebelumnya pernah diajukan Nasr Hamid Abu Zaid bahwa studi al-Qur'an, sebagaimana halnya studi hadis, terbatas hanya mengulang dan mengulang. Hal ini terjadi karena banyak di antara ulama yang mempunyai asumsi bahwa dua jenis ilmu tersebut masuk dalam wilayah ilmu yang "sudah matang dan gosong", ${ }^{4}$ sehingga generasi kemudian tak lagi memiliki apa pun yang dapat disumbangkan pada apa yang telah dihasilkan generasi sebelumnya. ${ }^{5}$

Berdasarkan latar belakang di atas, maka upaya terobosan Fakultas Ushuluddin IAIN Antasari untuk menghadirkan dan mengembangkan bidang kajian fiqh al- $\underline{h} a d i t s$ dan syarah hadis patut diapresiasi. Hal itu barangkali akan menjadi salah satu jalan keluar untuk mengatasi kebuntuan studi kritik sanad dan matan hadis yang belakangan ini hampir mencapai titik jenuh. Studi fiqh al-badîts dan syarah hadis pada dasarnya bukan bidang yang baru sama sekali, karena telah lama menjadi objek kajian di kalangan para sarjana hadis. Namun, keberadaannya di Fakultas Ushuluddin Jurusan Tafsir Hadis masih belum dikembangkan secara memadai di tengah kuatnya dominasi studi kritik sanad dan matan hadis.

\section{Fiqh al-Hadîts sebagai Kajian Multidisipliner}

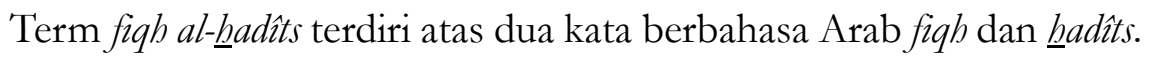
Untuk memperoleh pemahaman yang akurat mengenai apa yang dimaksud

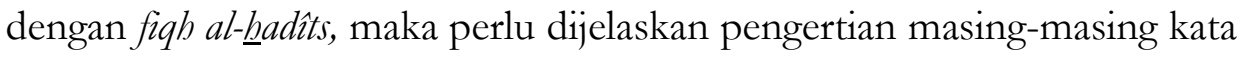
dari segi bahasa maupun istilah. Kata fiqh secara etimologis (bahasa) berarti pengetahuan, pemahaman, atau pengertian. ${ }^{6}$ Secara terminologis (istilah), fiqh didefinisikan sebagai "ilmu tentang hukum-hukum syar'iyyah amaliah

${ }^{4}$ Menurut sebagian ulama, ilmu-ilmu keislaman terbagi menjadi tiga kelompok: pertama, ilmu yang sudah matang dan belum terbakar, yakni ilmu nahwu dan ushûl; kedua, ilmu yang belum matang dan belum terbakar, yakni ilmu bayân dan tafsir; dan ketiga, ilmu yang sudah

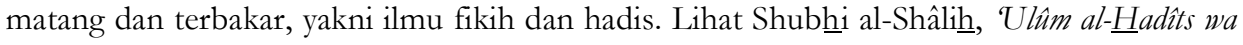
Mushthalabuhu, (Beirut: Dâr al-'Ilm li al-Malâyîn, 1988), h. 315.

${ }^{5}$ Nashr Hâmid Abû Zaid, Mafhum al-Nash: Dirâsat fî̀ 'Ulûm al-Qư'ân, (Beirut: al-Markaz al-Tsaqâfî al-'Arabî, 1990), h. 11.

${ }^{6}$ Ibn Manzhûr, Lisân al-'A rab, (t.t.: Dâr al-Ma'ârif, t.th.), jilid V, h. 3450; Ibrâhîm Mushthafâ et al., al-Mu'jam al-Wasith, (Kairo: Dâr al-Handasiyyah, 1405 H/1985 M), juz I, h. 724; Sa'dî Abû Habîb, Qâmûs al-FiqhîLughatan wa Ishthilâhan, (Damaskus: Dâr al-Fikr, 1419 H/1998 M), h. 289. 


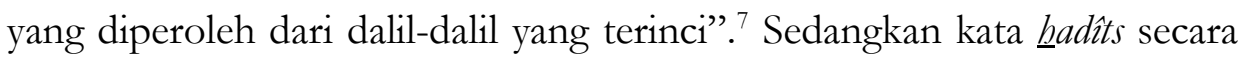
etimologis (bahasa) berarti baru dan berita. ${ }^{8}$ Secara terminologis (istilah), hadîts adalah "suatu yang disandarkan kepada Nabi saw. berupa perkataan, perkataan, perbuatan, persetujuan, maupun sifat."”

Kombinasi dari dua kata berbahasa Arab di atas kemudian melahirkan term fiqh al-badits. Secara sederhana term ini dapat diartikan sebagai pemahaman terhadap hadis Nabi saw. Istilah fiqh al-haditts dalam bahasa Arab disebut pula dengan fahm al-baditts. ${ }^{10}$ Secara lebih luas, Muhammad Thâhir al-Jawâbî mengajukan definisi dan ruang lingkup fiqh al-badîts sebagai berikut:

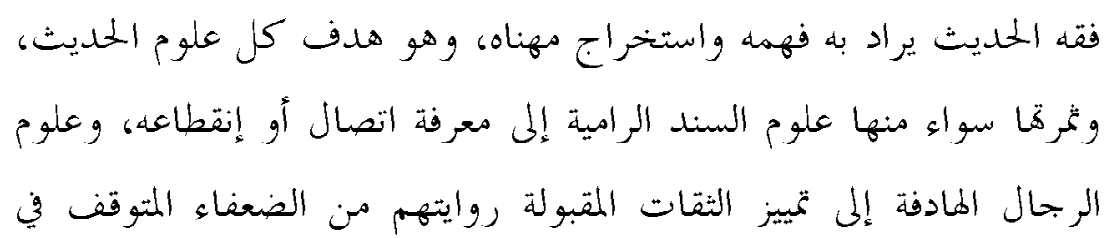

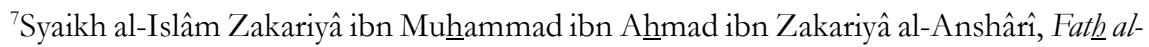
Wabhâb bi Syarh Minhaj al-Thullâb, ((Beirut: Dâr al-Kutub al-'Ilmiyyah, 1418 H/1998 M), h. 8; Syams al-Dîn Muhammad ibn Abi al-'Abbâs Ahmad ibn Hamzah ibn Syihâb al-Dîn al-Ramlî, Nihâyaț al-Mubtâj ilâ Syarh al-Minhâj;, (Beirut: Dâr al-Kutub al-'Ilmiyyah, 1424 H/2003 M), jilid I, h. 31; al-Syarîf 'Alî ibn Muhammad al-Jurjânî, Kitâb al-Ta'rifât, (Beirut: Dâr al-Kutub al'Ilmiyyah, 1408 H/1988 M), h. 168; Wahbaț al-Zuhailî, al-Fiqh al-Islâmî wa Adillatubu, (Damaskus: Dâr al-Fikr, 1422 H/2002 M), h. 30; 'Abd al-Wahhâb Khalaf, Tlm Ushûl al-Fiqh, (Kuwait: Dâr alKuwaitiyyah, 1388 H/1968 M), h. 11.

${ }^{8}$ Muhammad ibn Ya'qûb al-Fîrûz Âbâdî, al-Qâmûs al-Mubith, (Beirut: Dâr al-Jil, t.th.), juz I, h. 170; al-Thâhir Ahmad al-Zâwî, Tartîb al-Qâmûs al-Munith, (Riyadh: Dâr 'Âlam alKutub, 1417 H/1997 M), juz I, h. 600; Muhammad Shâdiq al-Munsyâwî, Qâmûs Mushthalabât

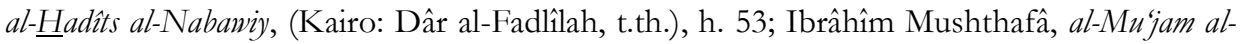
Wasith, jilid I, h. 166.

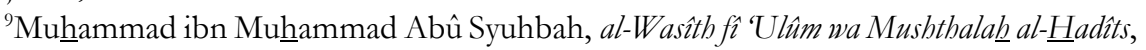
(Kairo: Maktabat al-Sunnah, 1427 H/2006 M), h. 13; Nûr al-Dîn 'Itr, Manhaj al-Naqdfì Ulùm alHadîts, (Damaskus: Dâr al-Fikr, 1418 H/1997 M), h. 26; Ibrâhîm Dasûkî al-Syahâwî, Mushthalab

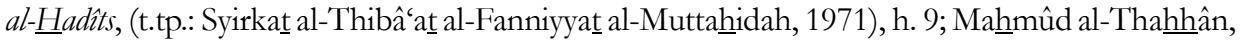

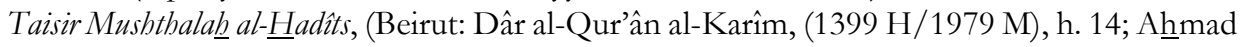

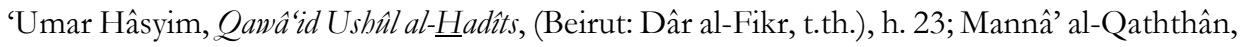

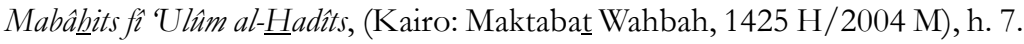

${ }^{10}$ Suryadi, Metode Memahami Hadis Nabi: Perspektif Mubammad al-Ghazali dan Yusuf alQaradhawi, (Yogyakarta: Teras, 2008), h. 67. Syekh Yûsuf al-Qaradhâwî, misalnya, menggunakan istilah fahm al-sunnah atau fahm al-badîts untuk merujuk pemahaman hadis Nabi saw. Lihat Yûsuf al-Qaradhâwî, Kaifa Nata'âmal ma'a al-Sunnat al-Nabawiyyah, (Kairo: Dâr al-Syurûq, 1423 H/2002 M), h. 111, 113, 175. 


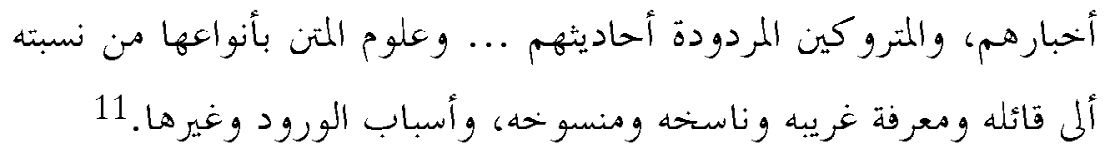

"Yang dimaksud dengan figh al-hadîts adalah memahami hadis dan mengeluarkan maknanya. Ia merupakan objek sasaran dari selurub ilmu badis, dan buah dari tiap-tiap ilmu hadis, baik menyangkut ilmu-ilmu sanad yang diarabkan untuk mengetahui ketersambungan atau keterputusan sanad, maupun ilmu-ilmu rijâl yang ditujukan untuk memisabkan antara periwayat-periwayat yang tsiqah yang diterima periwayatan mereka dan periwayat-periwayat yang dla îf yang didiamkan periwayatan mereka, serta periwayat-periwayat yang matrûk yang ditolak periwayatan mereka, dan ilmu-ilmu matan dengan segala macamnya, menyangkut penisbahan matan kepada pengucapnya, mengetahui matan yang gharib, nâsikh-mansûkh, asbâb al-wurûd, dan lain-lain."

Berdasarkan definisi dan cakupan di atas, maka bidang kajian fiqh alhadîts melibatkan hampir seluruh cabang disiplin ilmu hadis, baik menyangkut ilmu-ilmu sanad, ilmu-ilmu rijâl al-háadits, maupun ilmu-ilmu matan. Dengan demikian, fiqh al-badîts dapat dikatakan sebagai kajian multidisipliner. ${ }^{12}$ Dalam tiap-tiap ilmu tersebut terjalin kerjasama untuk memperoleh kejelasan maksud hadis Nabi saw. agar dapat diamalkan. ${ }^{13}$ Menurut al- Hâkim al-Naisâbûrî, mengetahui fiqh al-badîts merupakan buah dari ilmu-ilmu hadis, dan dengan fiqh al-badîts ini pula berdiri tegak syariat. ${ }^{14}$

Lebih lanjut, untuk memahami syariat agama secara benar tidak cukup dengan mengumpulkan hadis saja, tetapi juga diperlukan metode untuk memahaminya yang dikenal dengan fiqh al-badits ini. ${ }^{15}$ Karena itu, idealnya

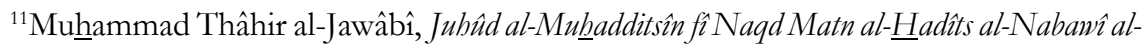
Syarif, (t.tp.: Mu'assasat 'Abd al-Karîm ibn 'Abdillâh, t.th.), h. 128.

${ }^{12}$ Kajian multidisipliner merupakan kajian (penelitian) menurut disiplin ilmu masingmasing, kemudian digabungkan secara eksternal sebagai satu kesatuan penyelenggaraan kajian (penelitian). Lihat Cik Hasan Basri, "Pengembangan Ilmu Agama Islam Melalui Penelitian Antardisiplin dan Multidisiplin", dalam M. Deden Ridwan (ed.), Tradisi Baru Penelitian Agama Islam: Tinjauan Antardisiplin Ilmu, (Bandung: Penerbit Nuansa, 2001), h. 53.

${ }^{13}$ al-Jawâbî, Jubûd al-Mụbadditsîn..., h. 128.

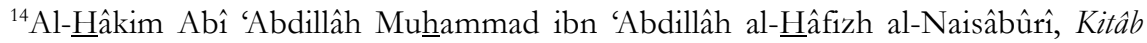

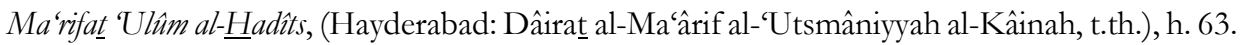

${ }^{15}$ M. Abdurrahman, "Kata Pengantar”, dalam M. Alfatih Suryadilaga (ed.), Studi Kitab Hadis, (Yogyakarta: Penerbit Teras, 2003), h. xv. 
seorang ahli hadis sekaligus juga sebagai ahli fikih. Bahkan, al-A'masy pernah mengungkapkan bahwa hadis yang diedarkan para ahli fikih (fuqahâ) lebih bagus daripada hadis yang diedarkan para guru hadis (syuyukkb), yang bukan ahli fikin.$^{16}$ Dengan begitu, ilmu fikih penting pula dikuasai, di samping ilmu hadis. Bila dalam diri seorang ulama tidak terkumpul dua keahlian itu, maka dikhawatirkan akan terjadi salah persepsi dan pemahaman yang tidak benar terhadap hadis, terutama jika diriwayatkan secara maknaw

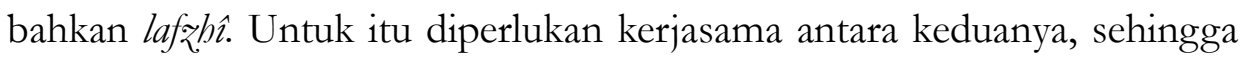
hadis tidak sekadar terakumulasi dalam kitab hadis, melainkan benar-benar menjadi dasar referensial umat Islam. Karena itulah, sering dianalogikan bahwa ahli hadis ibarat apoteker, sedangkan ahli fikih sebagai dokternya. Masing-masing saling membutuhkan, sehingga ajaran Islam dapat dibuktikan kesempurnaannya dan dapat pula diamalkan ajarannya secara benar. ${ }^{17}$

Studi fiqh al-hadits juga mempunyai hubungan yang erat dan tidak dapat dipisahkan dengan syarah hadis (syark al-badîts). Secara historis, term syarah hadis pada dasarnya merupakan hasil dari sebuah proses transformasi dari istilah yang telah ada sebelumnya yakni fiqh al-badîts. ${ }^{18}$ Kata syarah sendiri secara etimologis (bahasa) mengandung arti keterangan, penjelasan, atau penguraian. ${ }^{19}$ Sedangkan menurut istilah ahli hadis, syarah adalah uraian dan penjelasan hadis-hadis Nabi saw. yang termaktub dalam suatu kitab hadis tertentu. Uraian dan penjelasan itu bukan hanya berkenaan dengan makna, kandungan dan sabab al-wurûd-nya saja, tetapi juga hubungannya dengan keterangan dan dalil-dalil lain yang bersumber dari al-Qur'an, hadis, ataupun kaidah-kaidah syara' lainya, dan juga berisi penjelasan tentang takhrîj hadis-hadis bersangkutan, dan bahkan di antaranya juga memuat penilaian hadis-hadisnya. ${ }^{20}$

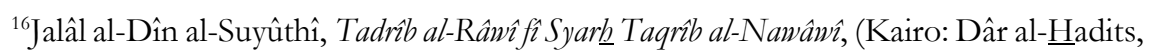
1423 H/2002 M), h. 28.

${ }^{17}$ Abdurrahman, "Kata Pengantar", h. xv.

${ }^{18}$ A. Hasan Asy'ari Ulama'i, “Sejarah dan Tipologi Syarah Hadis”, Teologia, vol. 19, no. 2, Juli 2008, h. 340.

${ }^{19}$ Ibn Manzhûr, Lisân al-'Arab, jilid IV, h. 2228; M. Syuhudi Ismail, Pembahasan Kitabkitab Hadis, (Ujung Pandang: t.p., 1989), h. 28.

${ }^{20}$ M. Syuhudi Ismail, Pembahasan Kitab, h. 28; M. Syuhudi Ismail, Pengantar Ilmu Hadits, (Bandung: Angkasa, 1991), h. 126; Nawir Yuslem, Ulumul Hadis, (Jakarta: Mutiara Sumber Widya, 2001), h. 144. 
Dengan demikian, maka terdapat kesinambungan antara syarah dan fiqh al-badits. Kalaupun hendak dibedakan antara keduanya, maka syarah hadis lebih bersifat konkret operasional yang berwujud tulisan dalam beberapa kitab yang berisi penjelasan ulama dari hasil pemahaman mereka terhadap suatu hadis. Sedangkan fiqh al-hadîts lebih bersifat konseptual, dan kalaupun dituangkan mungkin masih bersifat oral (penjelasan lisan). ${ }^{21}$

\section{Sejarah Perkembangan Fiqh al- $\underline{H}$ adîts}

Bidang kajian fiqh al-badîts pada tahap awalnya masih terbatas, kemudian tumbuh secara berangsur-angsur dan meluas hingga menjadi sebuah cabang ilmu yang dikenal dengan nama syarah hadis atau figh albadits. ${ }^{22} \mathrm{Hal}$ semacam ini juga biasa terjadi pada cabang-cabang ilmu lainnya yang pada tahap awalnya masih sederhana, kemudian melewati fase-fase perkembangan yang panjang hingga mencapai tahap kematangan dan menjadi ilmu yang berdiri sendiri.

Sejarah awal pertumbuhan fiqh al-badits tampaknya tidak dapat dilepaskan dari perjalanan historis periwayatan hadis. Sejarah periwayatan hadis secara pasti sudah berlangsung sejak periode Nabi saw. Ketika terjadi kegiatan periwayatan hadis dari Nabi saw. kepada para sahabat, selain melibatkan hafalan atau tulisan, seringkali juga terjadi proses pemahaman. Nabi saw. sendiri pernah mengungkapkan dalam salah satu hadisnya:

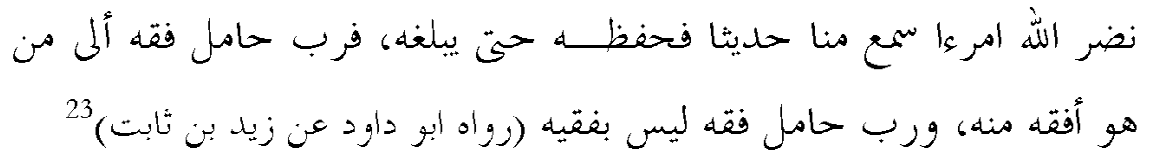

"Mudah-mudahan Allah mengaruniakan keelokan wajah kepada seseorang yang mendengar hadis dariku, kemudian menghafalnya sampai ia menyampaikannya (kepada orang lain). Banyak orang yang menerima pengetahuan (hadis) (kemudian menyampaikannya) kepada orang lain yang (ternyata orang lain itu) lebih paham daripada orang yang menyampaikannya, dan banyak orang yang menerima pengetahuan (hadis) (banya mampu menghafalnya) dan tidak memahami benar hadis itu." (Hadis diriwayatkan oleh Abûu Dâwud dari Zaid ibn Tsâbit)

${ }^{21}$ Asy'ari Ulama'i, "Sejarah dan Tipologi”, h. 340.

${ }^{22}$ al-Jawâbî, Juhûd al-Mubadditsîn, h. 129. 
Perjalanan historis pemahaman hadis (fiqh al-hadits) terus berlanjut hingga memasuki periode sahabat. Pada periode ini syarah atau fiqh alhaditts belum mempunyai bentuk tersendiri, artinya apa yang menjadi penjelasan sahabat terhadap hadis Nabi saw. belum dinamai syarah atau fiqh al-badîts, melainkan disebut sebagai atsar. ${ }^{24}$ Kalangan sahabat yang pernah hidup semasa dan berjumpa dengan Nabi terlibat dalam proses pemahaman hadis, dan terkadang terjadi perbedaan paham di antara mereka. 'Âisyah bint Abî Bakr, misalnya, terlibat perbedaan pendapat dengan 'Umar ibn al-Khaththâb ketika memahami hadis yang menyebutkan bahwa orang mati disiksa karena tangisan keluarganya. 'Umar ibn alKhaththâb memahami hadis ini dalam konteks redaksi yang umum. Sedangkan 'Âisyah bint Abî Bakr memahami hadis ini dalam konteks khusus, yakni orang mati dari kalangan Yahudi, selain juga menolak pemahaman 'Umar karena dinilai bertentangan dengan ayat al-Qur'an (Q.S. al-An'âm/6: 164). ${ }^{25}$

Perkembangan studi fiqh al-badîts yang lebih nyata terjadi pada periode

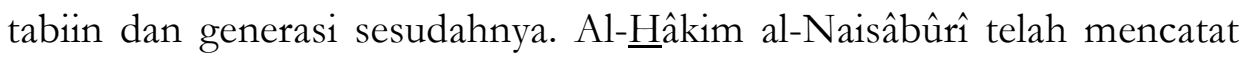
nama-nama ulama ahli fiqh al-hadîts, dari generasi tabiin, atbâ' al-tâbi î̀n, atbâ' atbâ' al-tâbi în, dan seterusnya. Di antara mereka adalah: Muhammad ibn Muslim ibn Syihâb al-Zuhrî, Yahyâ ibn Sa'îd al-Anshârî, 'Abd al-Rahmân ibn 'Amr al-Auzầî, Sufyân ibn 'Uyainah, 'Abdullah ibn Mubarak al- $\underline{\text { Hanzhalî, }}$ Yahyâ ibn Sa'îd al-Qaththân, 'Abd al-Rahnman ibn Mahdî, Yahyyâ ibn Yahyâa al-Tamîmî, A hִmad ibn Muhammad ibn $\underline{\text { H} a n b a l, ~ ' A l i ̂ ~ i b n ~ ' A b d i l l a ̂ h ~ i b n ~ J a ' f a r ~}$

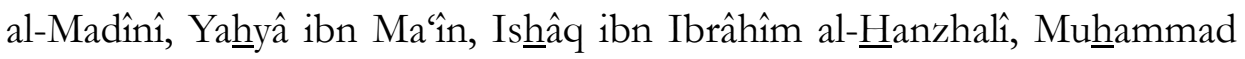
ibn Yahyâ al-Dzuhlî, Muhammad ibn Ismấîl al-Bukhârî, Abû Zur'ah 'Ubaidillâh ibn 'Abd al-Karîm, Abû Hâtim Muhammad ibn Idrîs al-

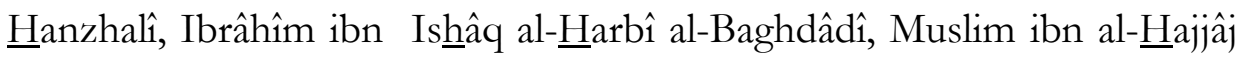
al-Qusyairî, Abû 'Abdillâh Muhammad ibn Ibrâhîm al-'Abdî, 'Utsmân ibn Sacîd al-Dârimî, Abu 'Abdillâh Muhammad ibn Nshr al-Marûzî, Abû 'Abd

\footnotetext{
${ }^{23}$ Abû Dâwud Sulaimân ibn al-Asy'ats al-Sijistânî al-Azdî, Sunan Abî Dâwud, (Dâr alMishriyyah al-Libnâniyyah, 1408 H/1988 M), juz III, h. 321.

${ }^{24}$ Ulama'i, "Sejarah dan Tipologi", h. 342.

${ }^{25}$ Rif'at Fauzî 'Abd al-Muthalib, Tautsîq al-Sunnah fî al-Qarn al-Tsânî al-Hijrî, (Mesir: Maktabat al-Khanjî, 1400 H/1981 M), h. 32; al-Jawâbî, Jubûd al-Munadditsîn, h. 460-461.
} 
al-Raḩmân Ahmad ibn Syu'aib al-Nasầ̂̂, dan Abû Bakr Muhammad ibn Ishâq ibn Khuzaimah. ${ }^{26}$

Studi fiqh al-hadìts justru mengalami perkembangan metodologis yang lebih signifikan pasca berakhirnya periode periwayatan hadis. Dalam periodisasi sejarah hadis, setidaknya mulai pertengahan abad VII H sampai sekarang, berlangsung apa yang disebut sebagai "ahd al-syar $\underline{b}$ wa al-jam' wa al-takbrîj wa al-bahts" (periode pensyarahan, penghimpunan, pen-takbrijan, dan pembahasan). ${ }^{27}$ Pada periode ini muncul kitab-kitab syarah hadis,

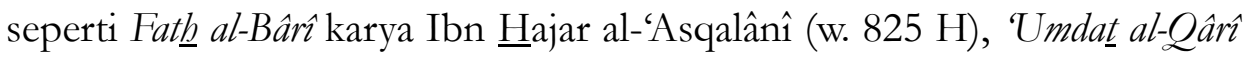
karya Muhammad ibn Ahmad al-'Ainî (w. 855 H), Irsyâd al-Sârî karya Muhammad al-Qashthalânî (w. 923 H), al-Minhaj karya al-Nawâwî (w. 676 H), Ikmâl al-Ikmâl karya al-Zawâwî (w. 743 H), 'Aun al-Ma 'bûd karya Syams

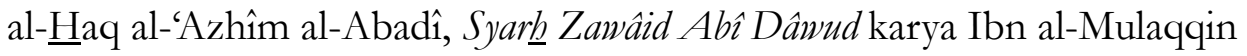
(w. 804), Syarh Zawâid Jâmi' al-Tirmidẓ̂̉ karya Ibn al-Mulaqqin (w. 804), Mishbâh al-Zujâjah karya al-Suyûthî (w. $911 \mathrm{H}$ ), Subul al-Salâm karya Ismấîl al-Shan'ânî (w. 1182 H), dan Nail al-Authâr karya al-Syaukânî (w. 1250 H). ${ }^{28}$ Kitab-kitab syarah hadis ini menjadi sumber utama bagi kajian figh al-badits.

Sepanjang sejarah perkembangan figh al-hadits, secara garis besar terdapat dua kelompok aliran dalam memahami hadis Nabi saw. Pertama, kelompok yang lebih mementingkan makna lahiriah teks hadis, yang disebut dengan Abl al- $\underline{H}$ adits, tekstualis. Kedua, kelompok yang mengembangkan penalaran terhadap faktor-faktor yang ada di belakang teks hadis, yang disebut dengan $A b l$ al-Ra'yî, kontekstualis. ${ }^{29}$ Kecenderungan terhadap pemahaman hadis yang lebih bercorak tekstualis dan kontekstualis sesungguhnya telah muncul sejak periode sahabat, dan kemudian mengalami perkembangan secara lebih luas pada periode tabiin atau setelahnya dengan munculnya kelompok Abl al- $\underline{H}$ adits yang berpusat di Madinah dan Abl alRa'yî yang berpusat di Irak.

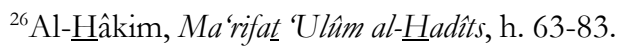

${ }^{27}$ M. Hasbi Ash-Shiddieqy, Sejarah Perkembangan Hadits, (Jakarta: Bulan Bintang, 1988), h. 123; Syuhudi, Pengantar Ilmu Hadits, h. 124; Yuslem, Ulumul Hadis, h. 142.

${ }^{28}$ Ash-Shiddieqy, Sejarah Perkembangan Hadits, h. 133-134; Syuhudi, Pengantar Ilmu Hadits, h. $127-128$.

${ }^{29}$ Suryadi, Metode Memahami Hadis Nabi, h. 73. 


\section{Metodologi Fiqh al- $\underline{\text { Hadîts }}$}

Seiring dengan perjalanan historis fiqh al-baditts, secara metodologis fiqh al-hadits juga mengalami perkembangan secara bertahap. Muhammad Thâhir al-Jawâbî menyebutkan tiga tahapan metodologis fiqh al-badîts, yakni:

1. Metode fiqh al-badîts yang terjadi bersamaan dengan proses tadwîn hadis, yang disebut dengan tarâjim al-hadîts (interpretasi hadis);

2. Metode fiqh al-hadîts yang terjadi setelah berakhirnya tadwîn hadis, yang disebut dengan syarh (penjelasan) yang lengkap terhadap hadis atau kitab hadis atau kumpulan hadis-hadis terpilih; dan

3. Metode fiqh al-badîts yang lebih belakangan lagi yang disebut dengan ta'qîb (komentar) dan ta'lîq (anotasi). ${ }^{30}$

Dari penjelasan al-Jawâbî di atas, maka tinjauan metodologis terhadap fiqh al-hadîts tidak dapat dilepaskan dari metode syarah atau ta'lìq. Bahkan, pada tahapan kedua dan ketiga, fiqh al-badîts dapat dikatakan identik dengan syarah atau ta'lîq. Karena itu, dalam pembahasan berikut ini tidak dibedakan secara ketat antara bidang syarah dan fiqh al-badîts.

Al-Mubârkafûrî telah mengklasifikasikan kitab-kitab syarah atau fiqh al-ḅaditts ke dalam tiga kelompok metode syarah, yaitu:

1. al-Syarh bi qâla aqûl, yaitu kitab syarah hadis yang menempatkan matan pada awal susunan kitabnya, kemudian pensyarah memberikan keterangan atas matan tersebut secara langsung, seperti Syarb alMaqâshid dan al-Thawali' karya al-Ashfahânî.

2. al-Syarb biqaulibi, yaitu kitab syarah yang menempatkan matan hadis secara sempurna terlebih dahulu, kemudian pensyarah memberikan penjelasan maksud kalimat tertentu dari matan hadis tersebut, umumnya catatan atau penjelasan itu ditempatkan pada bagian tepi garis atau di bawah garis, seperti Syarh al-Bukhârî karya Ibn $\underline{\text { Hajar al- }}$ 'Asqalânî dan al-Kirmânî.

3. al-Syarb mazjan wa mamæuj, yaitu kitab syarah hadis yang menempatkan matan hadis dan syarahnya dalam satu kesatuan (bercampur), hanya saja keduanya dibedakan dengan istilah mim ( $)$ ) untuk matan dan

${ }^{30}$ al-Jawâbî, Jubûd al-Munadditsîn, h. 129. 
syin (ش) untuk syarahnya, atau dengan cara lain yang disusun seperti buku biasa hanya diberikan semisal catatan kaki. ${ }^{31}$

'Utsmân al-Khasyit telah mengajukan beberapa metode syarah atau fiqh al- $\underline{\text { hadits, }}$ di antaranya yang terpenting:

1. al-Syark al-tafshîlí (syarah rinci), yaitu syarah hadis yang memuat penjelasan tentang sanad dan nama-nama rijâl hadis sesuai dengan kaidah al-jark wa al-ta'dîl, lalu membicarakan persambungan sanad dan keterputusannya, menentukan kesahihan dan kedaifan hadis dengan menyebutkan letak kecacatannya bila ditemukan di dalamnya, kemudian menjelaskan matan hadis dari penjelasan kalimat perkalimat yang sulit (musykil) serta menerangkan fungsi dan penggunaan lafal tersebut dalam konteks nash, memberikan pemahaman terhadap susunan-susunan kalimat yang menyulitkan disertai pernyataan-pernyataan yang menguatkan (argumen) seperti syair Arab sebagai syâhid-nya, kemudian membandingkan matan hadis tersebut dengan matan hadis yang setema, dan selanjutnya melakukan istinbâth hukum serta menyebutkan hal-hal yang terkait langsung maupun tidak langsung dengan sanad dan matan hadis.

2. al-Syarb al-wasith (syarah menengah), yaitu syarah hadis yang berisi penjelasan secukupnya tentang lafal-lafal asing (gharî) dan susunan kalimat yang terkait, lalu memberikan keterangan secara ringkas tentang diterima atau tidaknya rijâl dari jalur sanad yang ada, baru kemudian menjelaskan secara global berupa faedah atau manfaat hadis tersebut, baik sanad maupun matannya, apabila hal itu dikehendaki.

3. al-Syarb al-wajîz (syarah ringkas), yaitu syarah hadis yang berisi penjelasan tentang hal-hal yang sulit dan tempat-tempat yang musykil dengan menyebutkan beberapa pokok permasalahan yang ada di dalamnya dengan ringkas sekali. ${ }^{32}$

Ditinjau dari segi bentuk (format) penyajiannya, kitab syarah atau fiqh al-badîts juga dapat dibagi menjadi tiga macam:

\footnotetext{
${ }^{31}$ Abû al-'Ulâ Muhammad 'Abd al-Rahnmân ibn 'Abd al-Rahîm al-Mubârkafûriy,

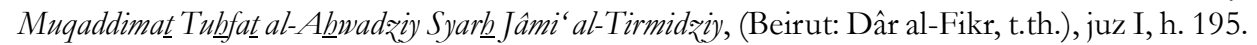

${ }^{32}$ Seperti dikutip dalam Ulama'i, "Sejarah dan Tipologi”, h. 345-346.
} 
1. Syarh , yakni penjelasan hadis yang umumnya ditempatkan pada bagian tengah bersama-sama dengan hadis yang disyarah. Menyangkut pengertian dan cakupan syar $\underline{b}$ sudah diuraikan pada bagian sebelumnya. Catatan penjelasan dalam bentuk syar $\underline{b}$ biasanya lebih luas yang mencakup berbagai aspek.

2. Hasyiyah, yakni penjelasan hadis yang umumnya ditempatkan pada bagian tepi (pinggir). Catatan pinggir semacam ini biasanya lebih singkat.

3. Ta'li $q$, yakni penjelasan hadis yang umumnya ditempatkan pada bagian bawah berupa catatan kaki atau anotasi. Catatan itu biasanya berupa keterangan singkat berkenaan dengan hal-hal penting dari hadis-hadis yang tercantum di atasnya. Karena merupakan catatan singkat, maka dengan sendirinya ta lì bukanlah berupa suatu kitab tersendiri, tetapi cukup mengikuti kitab-kitab hadis yang diberi catatan kaki atau anotasi. ${ }^{33}$

Sementara itu, ditinjau dari pendekatan keilmuan yang digunakan, kitab syarah atau figh al-hadîts terbagi menjadi tiga kelompok:

1. Syarah hukum, yaitu kitab syarah yang menggunakan pendekatan hukum (fikih) lebih menonjol dalam menjelaskan nash, seperti kitab Aujaz al-Masalik ila Muwaththa' karya Muhammad Zakariyâ alKandahlawî (w. 1392 H), Fath al-Allâm bi Ahâdîts al-Abkeâm karya Abû Yahyâ Zakariyâ al-Anshârî al-Syâfîî al-Khazrajî, dan lainnya.

2. Syarah kebahasaan, yaitu kitab syarah yang menggunakan pendekatan bahasa lebih menonjol dalam menjelaskan nash, seperti kitab 'Umdat al-Qârî karya Muhammad ibn Ahmad al-'Ainî (w. 855 H), al-Bukhârî bi Syarh al-Kirmânî karya al-Kirmânî, dan lain-lain.

3. Syarah komprehensif, yaitu kitab syarah yang menggunakan multi pendekatan dalam menjelaskan nash, hingga mencapai keseluruhan

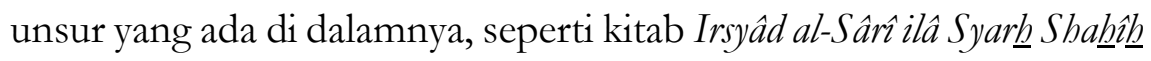
al-Bukhârî karya Syihâb al-Dîn A hịmad ibn Muhammad al-Qashthalânî (w. $923 \mathrm{H}) .^{34}$

\footnotetext{
${ }^{33}$ Syuhudi, Pembahasan Kitab, h. 29.

${ }^{34}$ Ulama'i, "Sejarah dan Tipologi", h. 354.
} 
Dari paparan di atas terlihat jelas bahwa metode syarah dan fiqh al-

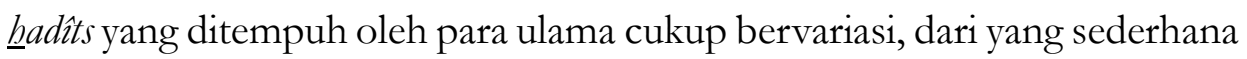
hingga yang komprehensif. Variasi seperti ini boleh jadi akan mempengaruhi tingkat ketepatan dalam memahami hadis Nabi saw. sebagai salah satu sumber syariat Islam. Ulama kontemporer, Syekh Yûsuf alQaradhâwî, mengajukan unsur-unsur kaidah yang lebih komprehensif dalam memahami hadis Nabi (fahm al-badîts), yang meliputi:

1. Memahami hadis di bawah sinaran al-Qur'an al-Karim;

2. Menghimpun hadis-hadis yang setema;

3. Mengkompromikan atau mentarjih hadis-hadis yang kontradiktif;

4. Memahami hadis sesuai dengan latar belakang, situasi dan kondisi, serta tujuannya;

5. Membedakan antara sarana yang berubah-ubah dan tujuan yang tetap bagi hadis;

6. Membedakan antara ungkapan haqîqah dan majâz dalam memahami hadis;

7. Membedakan antara yang gaib dan yang nyata; dan

8. Memastikan makna kata-kata yang terkandung dalam hadis. ${ }^{35}$

Terlepas dari penilaian bahwa delapan unsur kaidah di atas sangat sulit diterapkan dalam satu hadis tertentu, ${ }^{36}$ yang jelas beberapa unsur kaidah tersebut bila diterapkan secara tepat akan dapat mengantarkan kepada pemahaman hadis yang benar, dan juga terhindar dari sikap yang sewenang-wenang dan berlebih-lebihan.

\section{Penutup}

Dari paparan yang telah disajikan di muka, maka dapat ditarik simpulan sebagai berikut:

Studi fiqh al-hadîts merupakan bidang kajian multidisipliner yang melibatkan hampir seluruh cabang disiplin ilmu hadis, baik menyangkut ilmu-ilmu sanad, ilmu-ilmu rijâl al-badits, maupun ilmu-ilmu matan. Ilmu ini pada tahap awalnya masih sederhana, kemudian tumbuh secara ber-

${ }^{35}$ al-Qaradhâwî, Kaifa Nata'âmal, h. 113-197.

${ }^{36}$ Suryadi, Metode Memahami Hadis Nabi, h. 226. 
angsur-angsur dan meluas hingga menjadi sebuah cabang ilmu yang berdiri sendiri yang dikenal dengan nama syarah hadis atau fiqh al- $\underline{b}$ adîts.

Metodologi figh al-hadits telah mengalami perkembangan secara bertahap yang pada awalnya masih menyertai proses tadwin hadis, yang disebut dengan tarâjim al-hadîts, kemudian berikutnya mengambil bentuk syarh (penjelasan) yang lengkap terhadap hadis atau kitab hadis atau kumpulan hadis-hadis terpilih, dan lebih belakangan lagi mengambil bentuk ta'qîb (komentar) dan ta'lîq (anotasi). Ditinjau dari segi metode penyusunan, bentuk, dan pendekatan yang digunakan, ternyata karya-karya syarah dan figh al-hadits cukup bervariasi, dari yang sederhana hingga yang komprehensif [ ]

\section{DAFTAR PUSTAKA}

'Abd al-Muthalib, Rif'at Fauzî. Tautsîq al-Sunnah fì al-Qarn al-Tsânî al-Hijrî. Mesir: Maktabat al-Khanjî, 1400 H/1981 M.

Abdurrahman, M. "Kata Pengantar", dalam M. Alfatih Suryadilaga (ed.). Studi Kitab Hadis. Yogyakarta: Penerbit Teras, 2003.

Abû Dâwud, Sulaimân ibn al-Asy'ats al-Sijistânî al-Azdî. Sunan Abî Dâmud. Dâr al-Mishriyyah al-Libnâniyyah, 1408 H/1988 M.

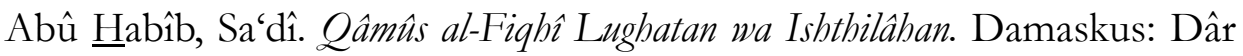
al-Fikr, 1419 H/1998 M.

Abû Syahbah, Muhammad ibn Muhammad. al-Wasith fî 'Ulûm wa Mushthala $\underline{\underline{h}}$

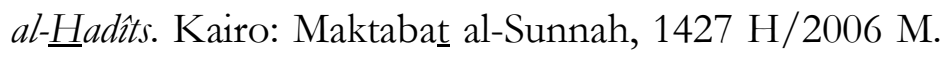

Abû Zaid, Nashr Hâmid. Mafhum al-Nash: Dirâsatfî̀ Ulûm al-Qur'ân. Beirut: al-Markaz al-Tsaqâfî al-'Arabî, 1990.

al-Anshârî, Syaikh al-Islâm Zakariyâ ibn Muhammad ibn Ahmad ibn Zakariyâ. Fath al-Wahhâb bi Syarh Minhaj al-Thullâb. Beirut: Dâr alKutub al-'Ilmiyyah, 1418 H/1998 M.

Basri, Cik Hasan. "Pengembangan Ilmu Agama Islam Melalui Penelitian Antardisiplin dan Multidisiplin”, dalam M. Deden Ridwan (ed.). 
Tradisi Baru Penelitian Agama Islam: Tinjauan Antardisiplin Ilmu. Bandung: Penerbit Nuansa, 2001.

al-Fîrûz Âbâdî, Muhammad ibn Ya'qûb. al-Qâmûs al-Mubîth. Beirut: Dâr al-Jil, t.th.

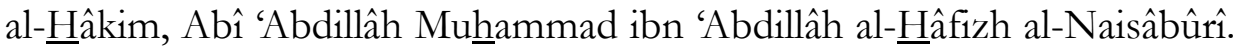

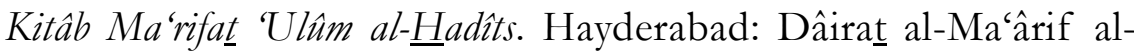
'Utsmâniyyah al-Kâinah, t.th.

Hâsyim, Ahmad 'Umar. Qawâìd Ushûl al- $\underline{H}$ adîts. Beirut: Dâr al-Fikr, t.th. Ibn Manzhûr. Lisân al-'Arab. t.tp.: Dâr al-Ma‘ârif, t.th.

Ichwan, Moch. Nur. "Beberapa Gagasan tentang Pengembangan Studi alQur'an dan Hadis: Refleksi atas Perkembangan Jurusan Tafsir Hadis di Indonesia”, dalam Sahiron Syamsuddin et al. Hermeneutika al-Qur'an Mą̧hab Yogya. Yogyakarta: Penerbit Islamika, 2003.

Ismail, M. Syuhudi. Pembahasan Kitab-kitab Hadis. Ujung Pandang: t.p., 1989. . Pengantar Ilmu Hadits. Bandung: Angkasa, 1991.

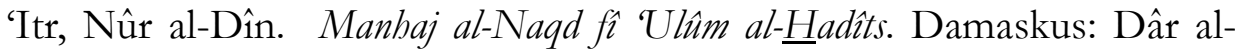
Fikr, 1418 H/1997 M.

al-Jawâbî, Muhammad Thâhir. Jubûd al-Mubadditsîn fî̀ Naqd Matn al- $\underline{H}$ adîts al-Nabawî al-Syarîf. T.t.: Mu'assasat 'Abd al-Karîm ibn 'Abdillâh, t.th.

al-Jurjânî, al-Syarîf 'Alî ibn Munammad. Kitâb al-Ta'rîfât. Beirut: Dâr alKutub al-'Ilmiyyah, 1408 H/1988 M.

Khalaf, 'Abd al-Wahhâb. Tlm Ushûl al-Fiqh. Kuwait: Dâr al-Kuwaitiyyah, $1388 \mathrm{H} / 1968 \mathrm{M}$.

al-Mubârkafûriy, Abû al-'Ulâ Muhamamad 'Abd al-Raḩmân ibn 'Abd al-

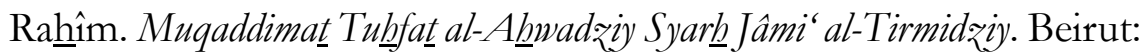
Dâr al-Fikr, t.th.

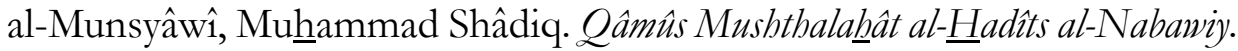
Kairo: Dâr al-Fadlîlah, t.th. 
Mushthafâ, Ibrâhîm et al. al-Mưjam al-Wasîth. Kairo: Dâr al-Handasiyyah, $1405 \mathrm{H} / 1985 \mathrm{M}$.

al-Qaradhâwî, Yûsuf. Kaifa Nata'âmal ma'a al-Sunnat al-Nabawiyyah. Kairo: Dâr al-Syurûq, 1423 H/2002 M.

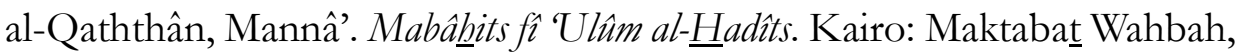
$1425 \mathrm{H} / 2004 \mathrm{M}$.

al-Ramlî, Syams al-Dîn Muhammad ibn Abi al-'Abbâs Ahmad ibn Hamzah ibn Syihâb al-Dîn. Nihâyat al-Mubtâj ilâ Syarh al-Minhâj. Beirut: Dâr al-Kutub al-'Ilmiyyah, 1424 H/2003 M.

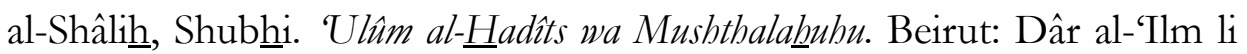
al-Malâyîn, 1988.

Ash-Shiddieqy, M. Hasbi. Sejarah Perkembangan Hadits. Jakarta: Bulan Bintang, 1988.

Suryadi. Metode Memahami Hadis Nabi: Perspektif Muhammad al-Ghazali dan Yusuf al-Qaradhawi. Yogyakarta: Teras, 2008.

al-Suyûthî, Jalâl al-Dîn. Tadrîb al-Râwî fî Syarh Taqrîb al-Nawâwî. Kairo: Dâr al- Hadits, $1423 \mathrm{H} / 2002 \mathrm{M}$.

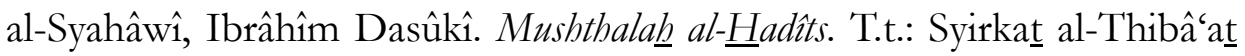
al-Fanniyyat al-Muttahidah, 1971.

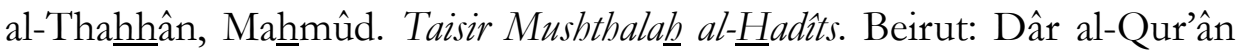
al-Karîm, 1399 H/1979 M.

Ulama'i, A. Hasan Asy'ari. "Sejarah dan Tipologi Syarah Hadis". Teologia, vol. 19, no. 2, Juli 2008.

Yuslem, Nawir. Ulumul Hadis. Jakarta: Mutiara Sumber Widya, 2001.

al-Zâwî, al-Thâhir Angmad. Tartîb al-Qâmûs al-Muhîth. Riyadh: Dâr 'Âlam al-Kutub, 1417 H/1997 M.

al-Zuhailî, Wahbat. al-Figh al-Islâmî wa Adillatuhu. Damaskus: Dâr al-Fikr, $1422 \mathrm{H} / 2002 \mathrm{M}$. 